\title{
Wettbewerb in der Privatrechtsgesellschaft
}

\author{
Erweiterte Fassung der 1. Franz-Böhm-Vorlesung am 19. September 2017 in \\ Freiburg
}

[Competition in Private Law Society. Extended Edition of the Böhm Lecture held on the 19 th of September 2017 in Freiburg.]

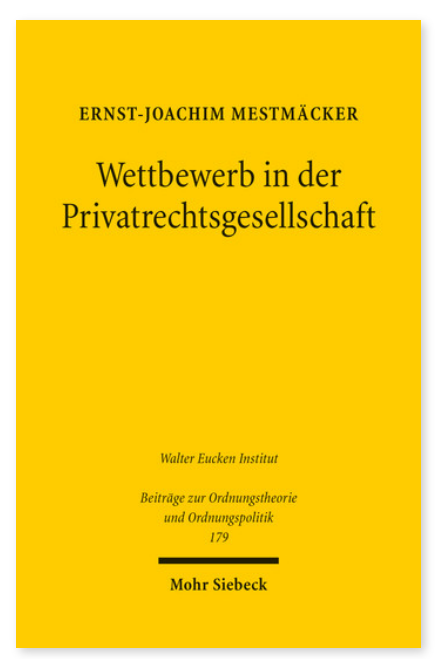

2019. 63 pages. BOrd 179

ISBN 978-3-16-155911-2

paper $24,00 €$

ISBN 978-3-16-155912-9

eBook PDF $24,00 €$

\section{Published in German.}

The legal scholar Franz Böhm joins the eminent economists Walter Eucken and F. A. von Hayek in the yearly memorial lectures sponsored by the Walter Eucken Institute. Together these three explored the founding and legitimizing principles of the market economy as a system for free and equal citizens within a democracy. Ernst-Joachim Mestmäcker illustrates how Franz Böhm established the theory of economic constitution, encompassing competition and the private law society, and showing that free societies are dependent on rules to facilitate peaceful cooperation, the most important of which are the non-utilitarian rules of private law. Since John Locke, it is known that these protect the individual rights of citizens and legally ensure that they are able to fulfill their own life plans. Böhm's theory reinforces these insights and in the light of current criticism of market economies, confirms the present political relevance of ordoliberal theory.

Ernst-Joachim Mestmäcker Geboren 1926; 1950 Erstes und 1954 Zweites Juristisches Staatsexamen; 1953 Promotion; 1958 Habilitation; Lehrbefugnis für Bürgerliches Recht, Handelsrecht und Wirtschaftsrecht; 1959-63 Professuren für diese Fächer an der Universität des Saarlandes, 1965-69 an der Universität Münster und 1969-78 an der Universität Bielefeld; 1978-94 Wissenschaftliches Mitglied und Direktor am Max-Planck-Institut für ausländisches und internationales Privatrecht in Hamburg; seither Emeritus.
Order now:

https://www.mohrsiebeck.com/en/book/wettbewerb-in-der-privatrechtsgesellschaft-9783161559112?no_cache=1 order@mohrsiebeck.com

Phone: +49 (0)7071-923-17

Fax: +49 (0)7071-51104 